\title{
Environmental policy commitment of North Sumatera provincial government in climate change mitigation efforts (case study of mangrove protection)
}

\author{
Antonio Marro Sipayung ${ }^{1 *}$ dan Henri Sitorus ${ }^{2}$ \\ ${ }^{1}$ Researcher, WALHI (Indonesia Forum for Environment) Province North Sumatera, Indonesia \\ ${ }^{2}$ Researcher at Postgraduate of Sociology Program, Universitas Sumatera Utara, Medan 20155 , \\ Indonesia
}

\begin{abstract}
The purpose of the study is to evaluate the policy commitment of North Sumatera provincial government in mitigating climate change (case study of mangrove protection). The Regional Action Plan for Greenhouse Gas (RAD-GRK) has been adopted in 2012 by the Province of North Sumatra. The action plan identifies action needed to rehabilitate mangroveswithin or outside of forest conservation areas. The action plan aimed for reforestation of 50,000 ha mangroves areas. However, data showed that by 2017 the North Sumatra government has only been able to rehabilitate $4,765 \mathrm{Ha}$ of mangrove forest. On the other hand, mangroves conversion to non forest land continues including conversion to oil palm plantations in Langkat District. Based on the qualitative data of interview with policy makers at the Provincial of North Sumatera and document analysis particularly from the government agencies, the research discovers that the policy commitment of the local government for mangroves protection is weak.
\end{abstract}

\section{Introduction}

The increasing concentration of greenhouse gases $\left(\mathrm{CO}_{2}, \mathrm{CH}_{4}, \mathrm{CFC}, \mathrm{HFC}, \mathrm{N}_{2} \mathrm{O}\right)$, particularly the increase of $\mathrm{CO}_{2}$ concentration, in the atmosphere cause global warming which trigger global climate change. This phenomenon has severely affected and hamper the sustainability of human life and other living organism, including the shifting of seasons and changes in the pattern/distribution of rain that trigger floods and landslides during the rainy season and dry season drought, seawater that potentially drowns small islands and floods, and storms/waves that often devastate life-sustaining infrastructure in coastal areas [1].

The climate change has been in the policy agenda from local to global scale. It has been realized that many aspects of life are disrupted including by the climate change. One of the

* Corresponding author Phone: +62812 6346 4307, Email: sipayungantonio@gmail.com 
simplest examples is an increase in the surface temperature of the earth which causes many people to start feeling hot or hot. This is one of the simplest examples of climate change.

Global warming is the occurrence of increasing average temperatures of the atmosphere, the ocean and the earth's land. Historically, the planet Earth has warmed (and also cooled) over and over for 4.65 billion years. At this time, the earth faces rapid warming, which scientists consider to be attributable to human activity. This activity is the burning of fossil fuels, such as coal, petroleum, and natural gas, which release carbon dioxide and other gases known as greenhouse gases into the atmosphere. As the atmosphere gets richer in greenhouse gases, it becomes an insulator that holds more heat from the reflected sun from the earth [2].

The excessive release of emissions from the activity of organism metabolism or the result of decomposition into the free air is a form of contamination for the atmosphere which is basically negative to environmental conditions that will ultimately affect the weather or climate on a large scale. From the accumulation of small changes will lead to major changes. Carbon emissions in nature can have diverse forms in the form of $\mathrm{CO}_{2}$ (carbon dioxide) from the respiration of the organism and $\mathrm{CO}$ (carbon monoxide) from fossil or petroleum burning. Other activities such as burning, smoking, discharge of $\mathrm{CH}_{4}$ (methane) natural gas, greenhouse gases such as HFC (hydrofluorocarbon) or PFC (perfluorocarbon) and others also contribute to increased carbon gas in nature [3].

Indonesia as a country on the path of the world's crossroads and on the equator has felt the vast impact associated with extreme climate change. The rising sea surface causes many small sinking islands and the occurrence of abrasion/floods that impact on residential areas.

The Government of Province North Sumatra is one of 33 provinces in Indonesia. Policies in climate change mitigation efforts are contained in the Green House Gas Regional Action Plan (RAD-GRK) with Pergub No 36 of 2012 for the period of 2010-2020. RAD-GRK is derived from Perpres No. 61 of 2011 related to the National Action Plan for Greenhouse Gases (RAN-GRK). This is evidence of the Government of Indonesia's serious efforts to address climate change issues.

The Government of Province North Sumatra is one of 33 provinces in Indonesia. Policies in climate change mitigation efforts are contained in the Green House GasRegional Action Plan (RAD-GRK) with Pergub (Governor Rules No 36 year 2012 for the period of year 2010-2020. RAD-GRK is derived from Perpres (Presidencial Rules) No. 61 year 2011 related to the National Action Plan for Greenhouse Gases (RAN-GRK). This is evidence of the Government of Indonesia's serious efforts to address climate change issues.

The Government of Indonesia is committed to reducing emissions by $29 \%$ under business as usual by 2030 , or $41 \%$ with international assistance. "To reach a Paris agreement, all parties must contribute more, in mitigation and adaptation actions, especially developed countries, that is, by mobilizing funding of USD 100 billion USD by 2020 " President Jokowi's speech at the UNFCC Conference Paris 2015.

With an area of $473,607 \mathrm{~km}^{2}$,Sumatra is known as having extensive biodiversity. Because of its rich resources, UNESCO declared the Sumatran rainforest a world heritage site in 2004. In this island, between 9,000 and 10,000 species of plants have been identified, including 17 species of mangroves, which contribute to the rich diversity of fauna [4]. According to FAO (2007), mangroves are coastal forests found in sheltered estuaries and along riverbanks and lagoons in the tropics and subtropics, which have very important ecological and economic functions.[5] note that mangroves are "shrubs or trees that live adjacent to the intertidal zone and have adapted to a regime of widely varying salinities, and to periodic and sometimes prolonged inundation".[6] Elaborates this function by detailing the benefits of mangroves in their branches, root trunks, and bark, which all have particular functions. 
Mangrove forests are coastal forests that are always or regularly inundated by sea water and are affected by tides [7]. Mangrove is a general term used to describe tropical beach community varieties dominated by distinctive tree species and shrubs, which have the ability to grow in salt waters [8]. The mangrove ecosystem is dominated by plants of Rhizophora, Avicennia, Bruguiera, and Sonneratia In addition, the mangrove ecosystem also found plant types Ceriops, Xylocarpus, Acrostichum, Lumnitzera, Aegiceras, Scyphyphora, and Nypa [9].

The role of mangroves is critical to sustaining production in coastal fisheries, because they act as important nursery areas for fisheries species (Burke et al., 2001). In mitigating disaster, mangroves are able to reduce storm surge, hence potentially reducing the number of casualties. Another ecological contribution of mangroves is the ability to prevent erosion and abrasion. In this role, mangroves also stabilize soils and protect against erosion, as well as reducing the strength of winds from the sea [10].

As an ecosystem in the transition region between the sea and the land, mangrove will be the first type of ecosystem affected by the impact that will occur due to global climate change. As expressed by some experts, among them Field (1995) [11], most mangrove in various parts of the world will experience the condition of air temperature increase, hydrological regime change, sea level rise, and the increase and frequency and frequency of tropical storm disaster.

Mangrove is a plant community or an individual plant species that forms the community in tidal areas. Mangrove forests are a type of forest that is naturally affected by tidal seawater, flooded during high tides and free from puddles during low tides. The mangrove ecosystem is a system consisting of biotic and abiotic environments interacting within a mangrove habitat. Mangrove has a very high physiological adaptability, resistant to environment with high water temperature, wide area wide salinity fluctuation and anaerobic soil. One important factor in such physiological adaptation is the system of broadcasting in its roots [12].

\section{Research problem}

The research on "Policy Commitment of North Sumatera Provincial Government in Climate Change Mitigation Measures" is intended to know about: (1) How is the commitment of climate change mitigation policy in Provice North Sumatera? (2) How is the protection policy of mangrove forest in Province North Sumatera?

\section{Literature Review}

Climate is high closely related to weather changes [13], climate change and global warming can reduce agricultural production between 5-20 percent. Climate change is a condition marked by changing world climate patterns that result in an uncertain weather phenomenon. Climate change occurs due to changes in climate variables, particularly air temperature and rainfall that occur continuously over a long period of time between 50 to 100 years [14]. Climate change is also affected by unstable weather conditions as examples of unpredictable rainfall, frequent storms, extreme temperatures, drastic wind direction, and so on [15].

Mangrove has four specific functions that can affect the quality of coastal waters, namely: 1 . its ability to supply nutrients for the surrounding waters. In a study conducted by ecoton carrying more than 7 tons/ha/year of litter (dried leaves) produced by mangrove ecosystems on the coast of Surabaya. This result is equivalent to the productivity of 
mangrove ecosystems generally scattered from the tropics to sub-tropical litter. Mangrove plays an important role in the process this is because the litter contains $40 \%$ of watersoluble compounds converted into bacterial biomass less than 8 hours after falling into mangrove waters. This makes the mangrove area frequented by a variety of animals to get the nutrients. $90 \%$ of the number of fish caught within $10 \mathrm{~km}$ of the coast contains mangrovefragments in the gut. 2. Mangroves as aquatic bird habitat. As a fertile, nutrientrich ecosystem, the area is bustling with birds, even in the western (October-December) seasons of more than 5,000-20,000 bird populations that make up the region. 3 . The existence of mangrove plays an important role in the life cycle of some economically valuable biota such as crabs, shrimps, milkfish and other marine fish, because at the time of laying and breeding his children most of the biota cycles in coastal areas of mangrove, just after they will mature back to the high seas. This can be demonstrated by the high population of zooplankton (an important chain in the food web) its existence can connect between producer I and consumer I) most of these organisms will grow into fish, shrimp, crab and shellfish. 4. In addition, several types of mangrove trees such as Raw Tree (Rhizophora mucronata) and Fire-fire Tree (Avicennia marina) have the ability to accumulate (absorb and store in leaf organs, will and stems) of heavy metals contaminants, resulting in the presence of mangroves in brackish waters it plays a role to filter and reduce the level of heavy metal pollution in marine waters [16].

Therefore, an increase in atmospheric $\mathrm{CO}_{2}$ concentration is expected to stimulate crop growth under conditions of limited availability of water, carbon or nitrogen, but plant growth will not increase if the salinity level is too high for smooth water-taking by plants or when the availability of some nutrients is limited in availability

In the mangrove ecosystem there are several types of biological resources that can be utilized for human welfare. The economic benefits that can be obtained from mangrove forests are wood for building materials, firewood, charcoal materials, and pulp materials. Other products are honey, can also be processed into organic fertilizers, foodstuffs, medicines, beverages, home appliances, textile raw materials, and leather [17].

The provincial government of North Sumatra has a strategy to reduce greenhouse gas emissions for 2010-2020 period in 6 (six) sectors, namely agriculture sector (with 15 activities of mitigation action plan), forestry and peatland sector (with 6 core activities and 3 supporters), the energy sector (6 core activities and 8 supporting activities), the transportation sector (17 core activities and 5 supporters), the industrial sector ( 8 activities and 5 supporters), and the waste treatment sector (6 core activities and 5 supporters). Particularly in the forestry and peatland sectors, the North Sumatra provincial government plans to rehabilitate 50,000 ha of mangrove forest within the forest area and beyond the mangrove forest area [18].

\section{Research Method}

This research used qualitative descriptive method. The subject of research is related to the Policy Commitment of North Sumatera Provincial Government in mitigating climate change. There are two types of data used in this research, namely primary and secondary data, with the following details: (1) Primary Data: policy makers at the level of the Province of North Sumatra namely the Office of Environment, Forestry Service and Regional Development Planning Agency, (2) Secondary Data: reports, archives, documents, or notes, especially from government agencies that have to do with the focus of research studies. Technique of data retrieval by through observation, depth interview, and study of secondary material. 


\section{Result and Discussion}

The commitment of North Sumatra government to climate change mitigation efforts is far from good. The policy found in the field has not been in accordance with what is planned in the local action plan particularly in the forestry and land (mangrove forest). According to Ahmad Syafei Hutahuruk as Head of Forest and Land Rehabilitation Division of North Sumatra Province Forestry Office said that, the commitment to realize the regional gas-gas action plan is still not fully implemented. Prior to the change of regulation related to authority at the provincial level, there was a Mangrove Agency, specializing in mangrove forest. However, until 2015 there is still no significant activity done. Mangrove according to him has a function for the protection of the land from the threat of abrasion, play a role in reducing the greenhouse effect. Mangrove generates a lot of oxygen due to the density of mangrove forests is greater so that the absorption of carbon becomes larger. Reduced areas of mangrove forest also affect climate change. Ahmad Syafei added the forestry service needs funding support for the implementation of greenhouse gas (RAD-GRK) action plan.

In the regional action plan in the field of forestry and peatlands it is mentioned that the North Sumatra government is committed to rehabilitate mangrove forests covering 50,000 $\mathrm{Ha}$ in 2010-2020 period. However, from data in the forestry service per year 2015, mangrove rehabilitation activities that have been done covering 4,765 Ha (table 1). If estimated per year, should the North Sumatra provincial government to rehabilitate mangrove forest per year of 5,000 ha. The condition of mangrove forests in northern Sumatra is critical and needs to be rehabilitated. Data on the condition of mangrove forest in north sumatera per year 2015 indicates that there is an area of 59,584.90 Ha of mangrove forest in extremely critical condition and 98,301.21 Ha in critical condition (table 2).

Tabel 1 Mangrove Rehabilitation year 2011-2015(Ha)

\begin{tabular}{|c|c|c|c|c|c|c|c|}
\hline \multirow{2}{*}{ No } & \multirow{2}{*}{ District/City } & \multicolumn{5}{|c|}{ Planting per year/Ha } & \multirow{2}{*}{ Total } \\
\cline { 2 - 7 } & Deli Serdang & 2011 & 2012 & 2013 & 2014 & 2015 & \\
\hline 1 & Langkat & 500 & 1,754 & 1,436 & - & - & 3,690 \\
\hline 2 & Karo & - & - & - & - & - & - \\
\hline 3 & Dairi & - & - & - & - & - & - \\
\hline 4 & Simalungun & - & - & - & - & - & - \\
\hline 5 & Asahan & 11 & 32 & 14 & & & 57 \\
\hline 6 & South Tapanuli & - & - & - & - & - & - \\
\hline 7 & North Tapanuli & - & - & - & - & - & - \\
\hline 8 & Central Tapanuli & - & 157 & - & - & - & - \\
\hline 9 & LabuhanBatu & - & - & - & - & - & - \\
\hline 10 & Mandailing Natal & - & - & - & - & - & - \\
\hline 11 & TobaSamosir & - & - & - & - & - & - \\
\hline 12 & HumbangHasundutan & - & - & - & - & - & - \\
\hline 13 & Pakpak Bharat & - & - & - & - & - & - \\
\hline 14 & Samosir & - & - & - & - & - & - \\
\hline 15 & SerdanBedagei & - & - & - & - & - & \\
\hline 16 & Batubara & 42 & - & - & - & - & - \\
\hline 17 & & - & - & - & - & - & - \\
\hline 18 & North Padang Lawas & & & & & \\
\hline
\end{tabular}




\begin{tabular}{|c|c|c|c|c|c|c|c|}
\hline \multirow{2}{*}{ No } & \multirow{2}{*}{ District/City } & \multicolumn{5}{|c|}{ Planting per year/Ha } & \multirow{2}{*}{ Total } \\
\cline { 3 - 7 } & Padang Lawas & 2011 & 2012 & 2013 & 2014 & 2015 & \\
\hline 19 & - & - & - & - & - & - \\
\hline 20 & South LabuhanBatu & - & - & - & - & - & - \\
\hline 21 & North LabuhanBatu & 41 & - & - & - & - & - \\
\hline 22 & Nias & - & - & - & - & - & - \\
\hline 23 & North Nias & - & - & - & - & - & - \\
\hline 24 & West Nias & - & - & - & - & - & - \\
\hline 25 & South Nias & - & - & - & - & - & - \\
\hline 26 & Sibolga & - & - & - & - & - & - \\
\hline 27 & TanjungBalai & - & - & - & - & - & - \\
\hline 28 & P. Siantar & - & - & - & - & - & - \\
\hline 29 & Tebing Tinggi & & & & & & - \\
\hline 30 & Medan & - & - & - & - & - & - \\
\hline 31 & Binjai & - & - & - & - & - & - \\
\hline 32 & Padang Sidempuan & - & - & - & - & - & - \\
\hline 33 & GunungSitoli & - & - & - & - & - & - \\
\hline & Total & 652 & 2,033 & 2,060 & & 20 & 4,765 \\
\hline
\end{tabular}

Source: Forestry Institution, (2018)

Tabel 2 Mangrove Forest condition at Province North Sumatera per year 2015(Ha)

\begin{tabular}{|c|c|c|c|c|c|}
\hline \multirow{2}{*}{ No } & \multirow{2}{*}{ District/City } & \multicolumn{4}{|c|}{ Width and Mangrove Forest Condition } \\
\cline { 3 - 6 } & Deli Serdang & $6,300.91$ & $8,170.84$ & $3,326.83$ & $17,798.58$ \\
\hline 1 & Langkat & $13,526.90$ & $23,564.93$ & $13,559.11$ & $50,650.94$ \\
\hline 2 & Karo & - & - & - & - \\
\hline 3 & Dairi & - & - & - & - \\
\hline 4 & Simalungun & - & - & - & - \\
\hline 5 & Asahan & 940.17 & $7,506.74$ & $2,624.64$ & $11,071.55$ \\
\hline 6 & South Tapanuli & 186.97 & 479.39 & 29.64 & 696 \\
\hline & North Tapanuli & - & - & - & - \\
\hline 7 & Central Tapanuli & $3,889.61$ & $2,664.91$ & 376.71 & $6,932.23$ \\
\hline 8 & LabuhanBatu & $7,181.19$ & $8,383.39$ & $4,099.15$ & $19,663.73$ \\
\hline 9 & Mandailing Natal & 620.84 & $2,261.94$ & 455.49 & $3,338.27$ \\
\hline 10 & TobaSamosir & - & - & - & - \\
\hline 11 & - & - & - & - & - \\
\hline 12 & PumbangHasundutan & - & - & - & - \\
\hline 13 & Pakpak Bharat & - & - & - & - \\
\hline 14 & Samosir & - & - & - & $12.995,26$ \\
\hline 15 & Sergei & $7,962.99$ & $4.524,05$ & 508,22 & - \\
\hline 16 & Baubara & $6,553.64$ & $12.561,10$ & 517,29 & 19.632 \\
\hline 17 & Paluta & - & & & \\
\hline 18 & & & - & - & \\
\hline
\end{tabular}




\begin{tabular}{|c|c|c|c|c|c|}
\hline \multirow[b]{2}{*}{ No } & \multirow[b]{2}{*}{ District/City } & \multicolumn{4}{|c|}{ Width and Mangrove Forest Condition } \\
\hline & & $\begin{array}{c}\text { Extremely } \\
\text { Critical }\end{array}$ & Critcal & Good & Total $(\mathrm{Ha})$ \\
\hline 19 & Padang Lawas & - & - & - & - \\
\hline 20 & South LabuhanBatu & - & - & - & - \\
\hline 21 & North LabuhanBatu & $11,834.45$ & $10,129.05$ & $2,817.40$ & $24,780.90$ \\
\hline 22 & Nias & - & - & - & - \\
\hline 23 & North Nias & - & - & - & - \\
\hline 24 & West Nias & - & - & - & - \\
\hline 25 & South Nias & 512.54 & $16,383.11$ & 372.76 & $17,268.41$ \\
\hline 26 & Sibolga & - & - & - & - \\
\hline 27 & TanjungBalai & 74.59 & 2.22 & - & 76.91 \\
\hline 28 & P. Siantar & - & - & - & - \\
\hline 29 & Tebing Tinggi & - & - & - & - \\
\hline 30 & Medan & - & - & - & - \\
\hline 31 & Binjai & - & - & - & - \\
\hline 32 & Padang Sidempuan & - & - & - & - \\
\hline 33 & GunungSitoli & - & - & - & - \\
\hline & Total & $59,584.90$ & $98,301.21$ & $29,435.96$ & $187,322.07$ \\
\hline
\end{tabular}

Source: Foresrty Institution, (2018)

Faisal Abrani Siregar as head of the data processing and information control, unit of climate control said that the focus on climate change control units is on the waste sector in climate change mitigation and adaptation efforts. Mitigation activities in the form of garbage bank establishment and encourage the utilization of methane gas (waste of oil palm). Faisal added related to the condition of mangrove forests, mangrove land should be controlled. Mangrove has a function as a carbon catcher and abrasion holder then mangrove forests should be preserved.

Andriadi as staff of the economic planning, maritime and natural resources of the Regional Planning and Development Agency (Bappeda) said that the total reduction of total GHG emissions has been reported as $12.50 \mathrm{M}$ ton $\mathrm{CO}_{2}$ eq from 536 mitigation actions that have been implemented from various institutions. Total approved mitigation actions are 280 actions from 536 actions. For the forest and land sector, there are as many as 198 mitigation action and emission reduction activities recorded as $11.91 \mathrm{CO}_{2}$ eq. Priority of land on critical land for development there is an area of $\quad 279.864 \mathrm{Ha}$.

Findings in the field showed that the condition of mangrove forest has decreased due to the land conversion into oil palm plantation and fish farming Cases in district of Langkat (bubun villages and kwala serapuh villages) indicate that mangrove forests are massively converted into oil palm plantations of approximately 260 ha and illegally done. Mangrove forests are dammed and then dried making it easier to be cleared into oil palm plantations. Similarly, mangrove land is converted to shrimp ponds.

Damage to mangrove forests is also caused by the mining of marine sand. Marine sand mining activities have been ongoing since 2008. According to data from the Provincial Investment and Licensing Office of North Sumatra Province as of December 2016, in the district of Deli Serdang (subdistrict pantai labu) there are 8 marine mining permits granted permission to mine sea sand of 38 Million $\mathrm{m} 3$ with the need for airport expansion and port reclamation. Approximately there were 2,000 Ha mangrove forest had been destroyed by the marine sand mining activities. The condition of the mangrove forest has been destroyed 
and the distance of the settlement from the shoreline is only 50 metres. Communities living on the coast are threatened by drowning due to abrasion and flooding. This was the effect of the destruction of mangrove forests in their area.

\section{Conclusion}

The Government of Province North Sumatra does not yet have a good commitment in mitigating climate change (the case of mangrove forest). The large number of cases of mangrove land conversion into illegal oil palm plantations and the presence of sea sand mining activities can accelerate the rate of damage to existing mangrove forests. Preventive action and serious concern in rehabilitation of mangrove forest area need to be taken.

\section{References}

1. C. Kusmana, Mangrove response to global climate change: Biological and ecological aspects of mangroves. Department of Silviculture. Faculty of Forestry IPB. Bogor, (2010)

2. V. Darsono, Introduction to Environmental Science. Revised edition, (Yogyakarta, 1993)

3. H. Purnobasuki, The Role of Mangrove In Climate Change Mitigation. (Department of Biology, Airlangga University Surabaya. Bulletin PSL Airlangga University 18: 9-10, 2006)

4. H. Purnobasuki, Peranan Mangrove dalam upaya mitigasi perubahan iklim. Departemen Biologi. (Buletin PSL. Universitas Airlangga Vol 18: 9-10, 2006)

5. T. Whitten, S.J. Damanik, J. Anwar, N. Hisyam, The Ecology of Sumatra.The Ecology of Indonesia Series, (Oxford University Press, 2000)

6. L. Burke, Y. Kura, K. Kassem, C. Revenga, M. Spalding, and D. McAllister, Coastal ecosystems, (World Resources Institute, Washington DC ,2001)

7. C.L. Angell, Review of Critical Habitats: Mangroves and Coral Reefs. Bay of Bengal Large Marine Ecosystem (BOBLME) Theme Report (FAO BOBLME Programme. Regional Planning and Development, 2004)

8. W.A.M. Mae, A General Account of the Fauna and Flora of Mangrove Swamp and Forest in the Indo-West Pacific Region, Adv Mar. Bio, 6: 73 - 270. (1968)

9. J.W. Nybakken, Marine Biology, An Ecological Approach, (Gramedia, Jakarta, 1988)

10. Supriharyono, Conservation of Biodiversity Ecosystems in Coastal Areas and Tropical Seas. Learning Library, (East Celeban, Yogyakarta, 2009)

11. FAO, State of the world's forests. Rome: Food and Agricultural Organisation of the United Nations, (2005)

12. C.D. Field, Impact of expected climate change on mangroves, Hydrobiologia 295, 75 $81,(1995)$

13. S. Subekti, Global Warming and mangrove Management Efforts, (Faculty of Engineering, University of Pandanaran, Semarang, 2018)

14. Suberjo, Adaptation of Agriculture in Global Warming. (2009)

15. The Indonesian Ministry of Environment. Global Climate Changes, http://climatechange.menlh.go.id, (2004)

16. Ratnaningayu, From timor to krui: how farmers and fishermen face the impacts of climate change, Climate action, (Pelangi Indonesia, Jakarta, 2009) 
17. D.G. Bengen, Coastal and Marine Ecosystems and Resources and Integrated and Sustainable Management. (Center for Coastal and Marine Resource Studies IPB, Bandung, 2003).

18. Bappeda/ Regional Planning and Development Agency, Policy and Effort to Achieve Low Carbon Society in North Sumatera Province, (2016). 